\title{
FACTORS AFFECTING THE DESIGN OF A GRADING MACHINE FOR EGYPTIAN-LIME FRUITS
}

\author{
A.E.S El-Raie ${ }^{(1)}$, I. Yehia ${ }^{(2)}$, M. M. Atallah ${ }^{(3)}$ and K. S. Khalil ${ }^{(3)}$
}

\begin{abstract}
The aim of this research is to design a grading machine according to the physical and mechanical properties of lemon fruits.

The main results in this study can be summarized in the following points:

The maximum fruit damage of 4.7, 4.1 and $8.9 \%$ for fruit sizes 35, $40 \mathrm{~mm}$ and total count, respectively were obtained with grading speed of $8 \mathrm{rpm}$ $(0.08 \mathrm{~m} / \mathrm{s})$ and fruit batch of $20 \mathrm{~kg}$. Meanwhile, the minimum fruitdamage of zero \% for all fruit sizes was obtained with grading speed of 11 - $14 \mathrm{rpm}(0.12-0.15 \mathrm{~m} / \mathrm{s})$ and fruit batch of $5 \mathrm{~kg}$. The maximum range of grading-machine productivity for lemon fruits of $220.7-760.9 \mathrm{~kg} / \mathrm{h}$ was obtained with grading speed range of $5-14 \mathrm{rpm}(0.05-0.15 \mathrm{~m} / \mathrm{s})$ and fruit batch of $20 \mathrm{~kg}$. Meanwhile, the minimum range of gradingmachine productivity for lemon fruits of $142.8-492.3 \mathrm{~kg} / \mathrm{h}$ was obtained with grading speed range of $5-14 \mathrm{rpm}(0.05-0.15 \mathrm{~m} / \mathrm{s})$ and fruit batch of $5 \mathrm{~kg}$.
\end{abstract}

The operation and production costs were 7.37 L.E./h and 64.84, 19.8 L.E./ton at optimum conditions (grading speed of $11 \mathrm{rpm}$ or $0.12 \mathrm{~m} / \mathrm{s}$ and fruit batch of $10 \mathrm{~kg}$ ).

\section{INTRODUCTION}

$\mathrm{P}$ ost harvest sorting and grading of fruits is a difficult and labour intensive component of the commercial fresh fruit market.

area of citrus is 346.24 thousand feddans (145.42 thousand hectare) in 2002. The areas of orange, tangerine and lemon are about 210, 94 and 38 thousand feddans $(88.2,39.48$ and 15.96 thousand hectare), respectively. The total annual production of citrus in Egypt is about 2.8 million ton, in 2002. The productions of orange, mandarin (Citrus deliciosa. Blanco) and lemon are about 181, 602 and 334 thousand tons respectively.

(1), (2) and (3) Chief Res. and Res., Ag. Eng. Res. Inst. Respectively. 
The lemon is considered to be one of the most alkalinizing foods.

In Egypt, there are various mandarin varieties different in their productivity, fruit maturity and quality. Alternate bearing is one of the most disadvantages in Baladi mandarin, beside great number of seeds per fruit and small fruit size.

Abd-Alla et al. (2000) reported that:

1- The grading efficiency decreased with increasing both fruit feeding speed and tilt angle of grading unit.

2- The grading efficiency increased with the increase of critical distance from 0.04 to $0.1 \mathrm{~m}$ and start to decrease at critical distance of $0.13 \mathrm{~m}$.

3- The mass-grading machine consumes an average power of $0.0084 \mathrm{~kW}$ for potato varieties and $0.001 \mathrm{~kW}$ for orange variety.

4- The total cost of grading one ton of potato varieties was 13.15 L.E. in comparison with 9.05 L.E. for orange.

Mousa (1998) found that the mean values of diameter ranged from about 28.1 to 41.4 ; height ranged from about 26.7 to $40 \mathrm{~mm}$; mass ranged from about 15 to $35 \mathrm{~g}$; volume ranged from 17 to $40 \mathrm{~mm}^{3}$ for Egyptian lime. The height values limited the distance between grading lines and shape and size of the distributed buckets on the conveyor belt. According to that, the grading-pipes design was: the distances between two pipes for grading lime are 20 and $50 \mathrm{~mm}$ at the beginning and ending of grading line.

Mousa (1998) designed and tested a cylinders grading-machine for citrus. The optimum conditions were: grading speed of $70 \mathrm{rpm}(0.37$ $\mathrm{m} / \mathrm{s}$ ), and tilt angle of grading unit of $3-6^{0}$ which gave 4.2 ton $/ \mathrm{h}$, grading efficiencies of 56 and $44 \%$ for two sizes. 
Amin (1994) developed and tested a grading machine consisting of rotating cylinder and perforated concave to grade potato, onion and orange crops. The obtained results showed that crop parameters such as (cell area and shape, drum speed, slope of drum axle and drum length) have a significant effect on grading efficiency. The capacity of machine at optimum drum speed of 25 r.p.m. and slope of zero degrees was 1.2 $\mathrm{Mg} / \mathrm{h}$ with tuber damage of $0.23 \%$.

Radwan (2000) reported that the grading efficiency decreased with increasing both fruit feeding speed and tilt angle of grading unit. However, the grading efficiency increased with the increase of critical distance from 0.04 to $0.1 \mathrm{~m}$ and start to decrease at critical distance of $0.13 \mathrm{~m}$.

Yehia (2001) studied the physical and mechanical properties of Ponkan mandarin and used them to give a design idea of the grading machine as a case study. The theoretical calculations were:

Revolving drums with holes are used to grade the fruits to 5 sizes.

Drum hole diameters $=40,50,60,70$ and $80 \mathrm{~mm}$, No. of drums to suit No. of Ponkan mandarin categories $=5$, Rotating drums with holes diameter and length to suit machine productivity $=$ about $40-50 \mathrm{~cm}$ diameter and $100 \mathrm{~cm}$ length, Drums tilt-angle = more than maximum rolling angle between Ponkan mandarin fruits and stainless steal surface $=$ more than $24^{0}$.

The objective of present research is to study some physical and mechanical properties of Egyptian lime, as a data base to help the design of handling machines. The physical and mechanical properties are incorporated in the development of the grading machine as a case study.

\section{MATERIALS AND METHODS}

\subsection{Fruits.}

Lemon crop "Egyptian lime" variety was considered in this study. All measurements were done using a random sample of 100 fruits. The samples were taken randomly from lemon trees (special farm in El Qanater El Khairia at acceptable harvesting date) and from "El Oboor" Market; and the measurements were taken in the same day. 


\subsection{Designed grading-machine.}

The designed grading machine for lemon fruits consists of the following parts (fig. 1):

2.2.1. Fruit box: made of wood sheet with thickness of $6 \mathrm{~mm}$, top dimensions of $350 \times 330 \mathrm{~mm}$ and bottom dimensions of $350 \times 80 \mathrm{~mm}$. The rear side of hopper has the angle with horizontal plane of 60 degree (fig. 2a).

2.2.2 Fruit bin: made of wood sheet with thickness of $24 \mathrm{~mm}$ and dimensions of $800 \times 525 \times 270 \mathrm{~mm}$ (fig. 2b). The fruit box was supported

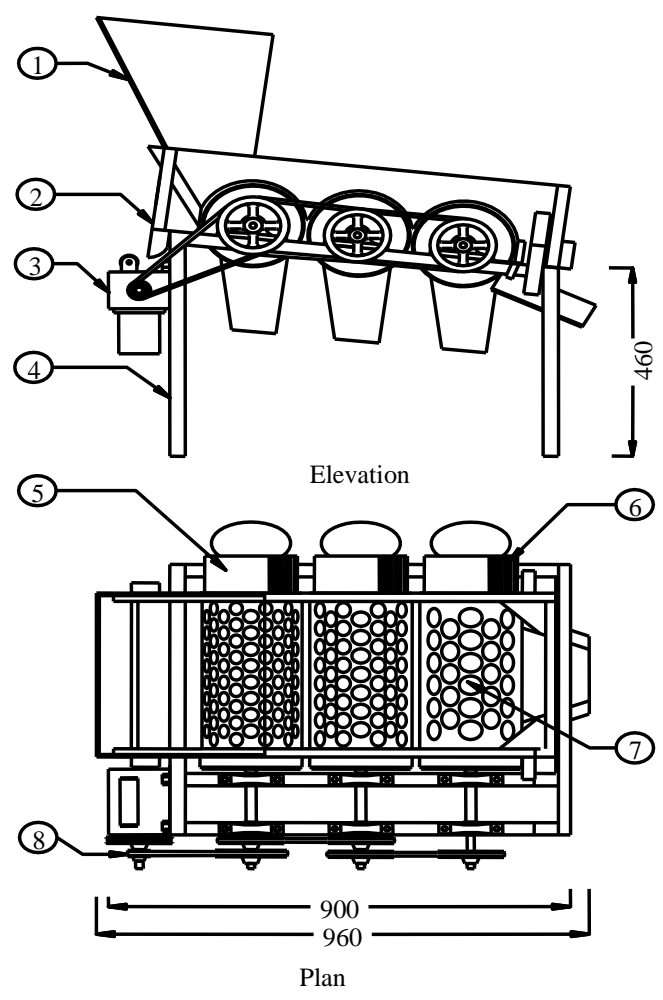

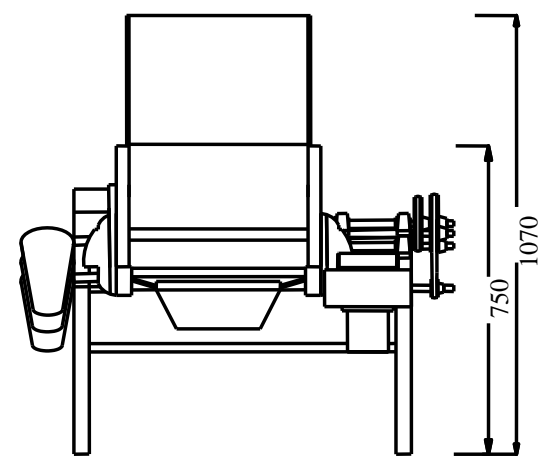

Side View Dim. in mm.

1- Fruit hopper (box).

2- Frame.

3- Motor.

4- Stand.

5- Chute.

6- Cutoff.

7- Revolving drum.

8- Transmutation system.

Dims. in mm

Fig. 1: Views of designed grading-machine for lemon fruits. 

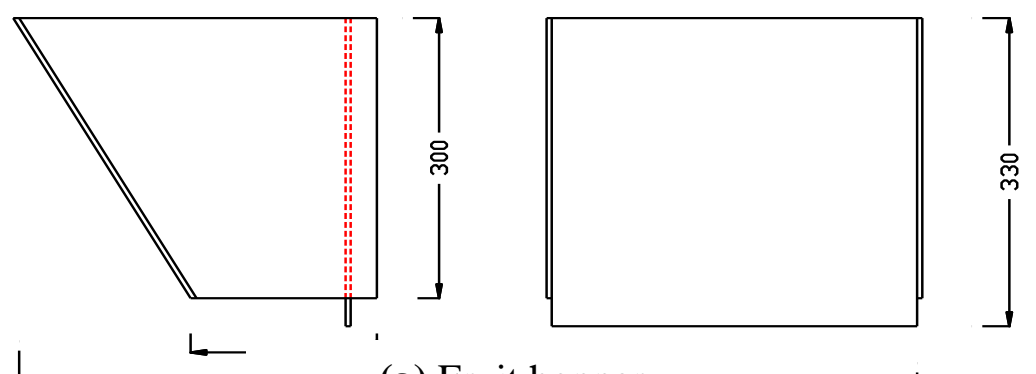

$340-$

(a) Fruit hopper.
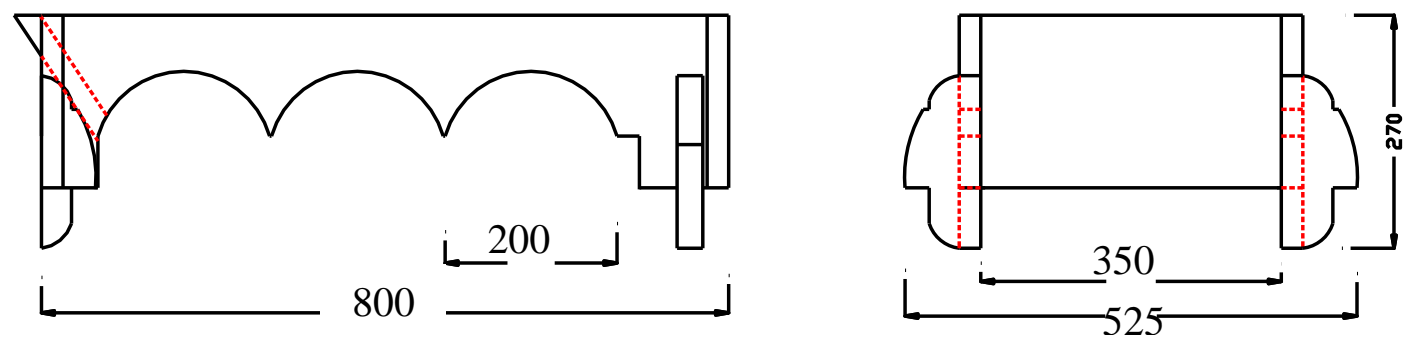

(b) Fruit bin.
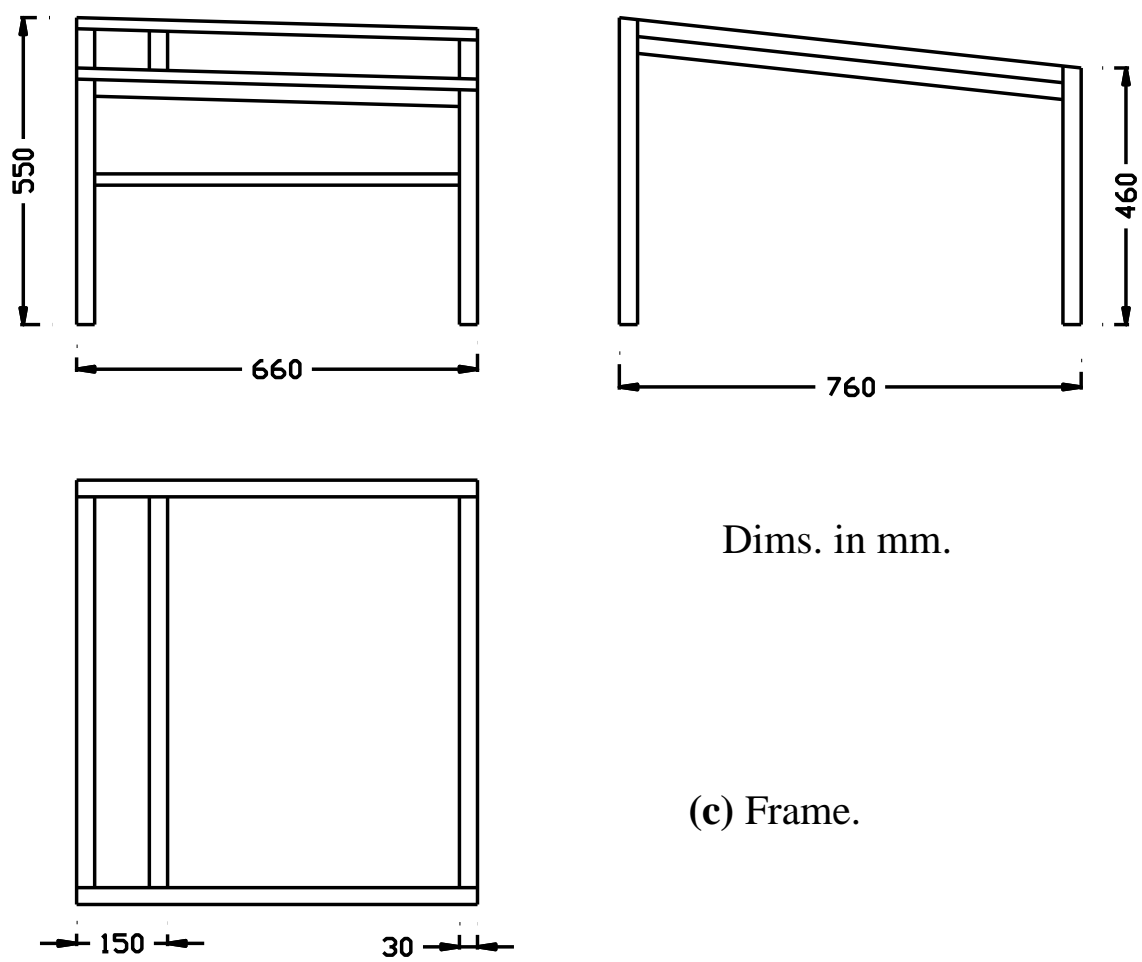

Dims. in mm.

(c) Frame.

Fig. 2: Views of fruit hopper, fruit bin and machine frame. 
with rear side of fruit bin by two bolts. The rear side of the fruit bin is inclined with horizontal plane by $7^{0}$.

2.2.3. Frame: made of iron angles with dimensions of $30 \times 30 \times 3 \mathrm{~mm}$ (fig. 2c). The frame has length of $760 \mathrm{~mm}$, width of $660 \mathrm{~mm}$ and rear height of $550 \mathrm{~mm}$ and front height of $460 \mathrm{~mm}$. The frame is inclined to front direction (grading-direction) by $7^{0}$.

2.2.4. Grading revolving-drums: three revolving drums made of PVC with diameter of $200 \mathrm{~mm}$ and length of $430 \mathrm{~mm}$, thickness of $4 \mathrm{~mm}$ and spacing $6 \mathrm{~mm}$ (fig. 3a). The three grading-drums have holes diameter of 35, 40 and $45 \mathrm{~mm}$ and number of holes of 111104 and 77 respectively. Iron metal-sheet of $35 \mathrm{~mm}$ length, $32 \mathrm{~mm}$ width and $1.5 \mathrm{~mm}$ thickness was assembled upper grading-drums spacing and bolted on two sides of fruit bin.

2.2.5. Fruit cutoff and chute: made PVC sheet with length of $450 \mathrm{~mm}$ and width of $160 \mathrm{~mm}$ (fig. 3b). Three fruit cutoffs were passed inside the three grading drums and were hinged with left side of frame by cantilevers. The fruits roll on the concaved part of cutoff (chute) and drop into funnels. The curved part prevents the jamming of fruits. The total inclined-angle of cutoff and chute is $11.5^{\circ}$.

2.2.6. Transmittion system and motor: consist of motor of $0.3 \mathrm{hp}(225$ $\mathrm{kW}$ ) and chains and sprockets as shown in fig. 4 .

2.6. Design steps and specifications of components of the grading machine:

Fig. 5 shows a schematic diagram of the designed grading-machine. Parameters shown on the figure are essentially those to be determined for lemon through this work, for modifying the grading machine to operate efficiently on this fruit.

The physical and mechanical properties are incorporated in the design of the fruit hopper, revolving drums with holes (length and diameters of drums, diameter of holes, and number of holes) and exit chute of the designed grading-machine as follows:

\subsubsection{Fruit hopper (Fig. 5):}

Hopper dimensions: to suit feeding rate and bulk density of fruits = top dimensions of $350 \times 330 \mathrm{~mm}$ and bottom dimensions of $350 \times 80 \mathrm{~mm}$. 
Fruit hopper side-slope $=$ more than maximum friction angle of lemon fruits with wood surface $\left(>43^{\circ}\right)=60^{\circ}$.
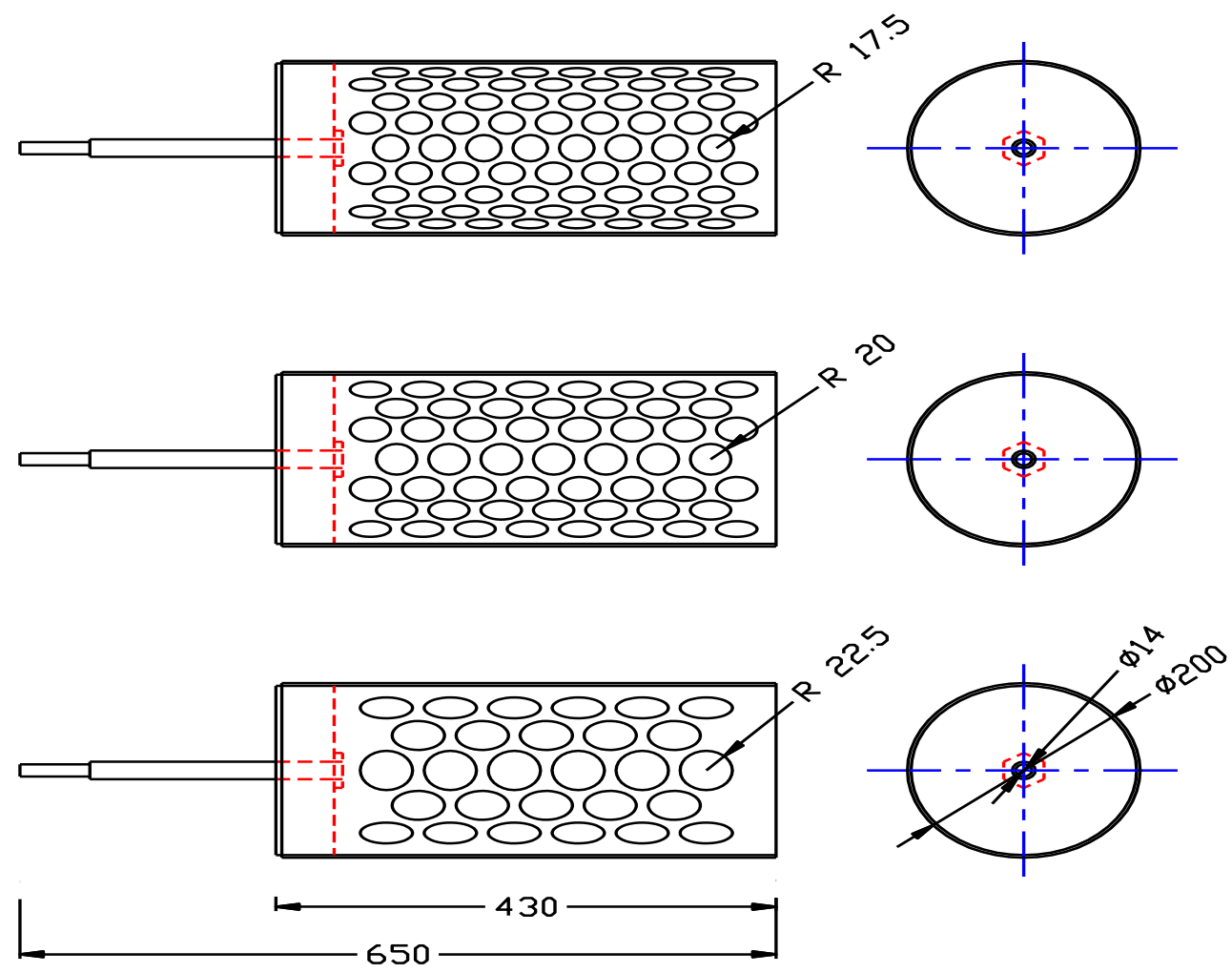

(a) Grading revolving-drums.

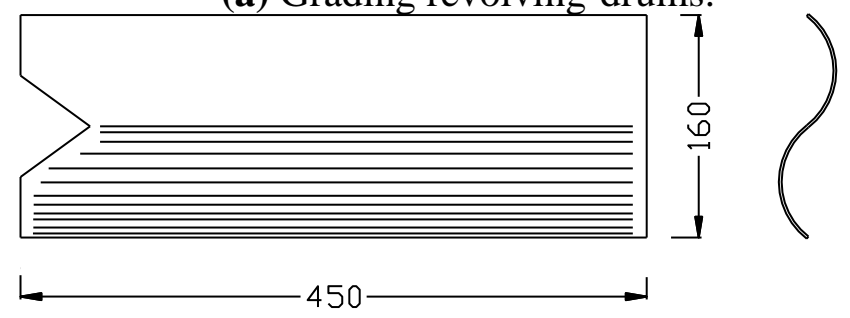

(b) Fruit cutoff. Dims. in mm.

Fig. 3: Views of grading revolving-drums and fruit cutoff. 

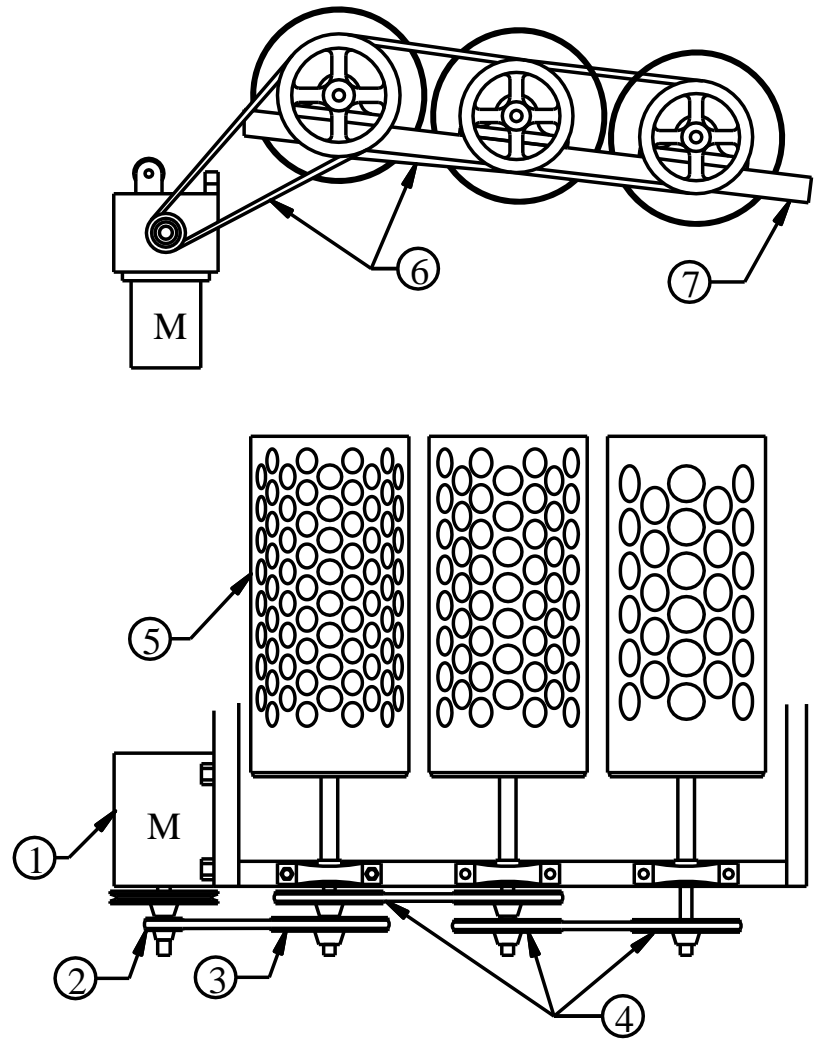

1- Motor.

2- Pulley Dim. 5mm.

3- Pulley Dim. 130 mm.

4- 4 Pulleys Dim. 120 mm.

5- Grading revolving-drum.

6- Belt.

7- Frame.

Fig. 4: Views of grading transmittion system of grading machine.

\subsubsection{Grading drums:}

Revolving drums with holes are used to grade the fruits to 3 sizes.

Drum hole diameters $=35,40$, and $45 \mathrm{~mm}$. The fruit $>45 \mathrm{~mm}$ exit from the end of the machine.

No. of drums to suit No. of lemon categories $=3$.

Rotating drums with holes diameter and length to suit machine productivity $=$ about $20 \mathrm{~cm}$ diameter and $100 \mathrm{~cm}$ length .

Drums tilt-angle at fruit exit direction $=$ more than maximum rolling angle between lemon fruits and PVC surface $=$ more than $24^{0}$.

Drums tilt-angle at drum-motion direction (found experimentally) $=7^{0}$.

\subsubsection{Fruit cutoff and chute:}

Fruit chute tilt-angle $=$ more than maximum rolling angle between lemon fruits and PVC surface $=$ more than $24^{\circ}=25^{\circ}$. 


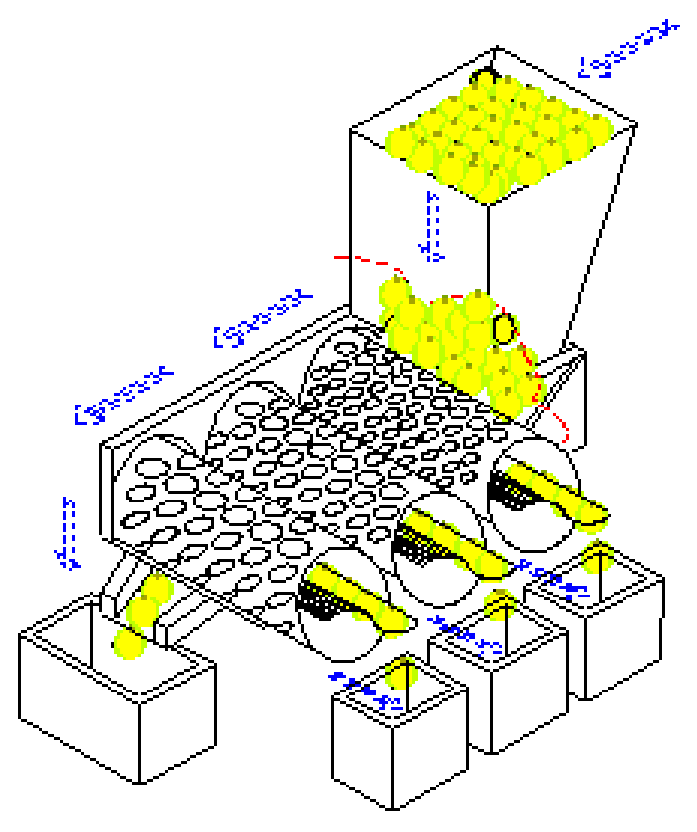

Fig. 5 : Schematic diagram of the designed grading-machine, with the numbers in brackets indicating parameters necessary for design of different parts.

\section{Associated parameters:}

(1) Fruit dimensions, (2) Bulk density, (3) Friction and rolling angles, (4) Fruit mass, and (5) Fruit firmness.

\subsection{Instrumentation:}

2.3.1. Digital caliper with vernier: with accuracy of $0.01 \mathrm{~mm}$, to measure different dimensions of limon fruits.

2.3.2. Digital balance: with accuracy of $0.2 \mathrm{~g}$, to measure mass of Ponkan-mandarin fruits and constituents (peel, seeds and juice).

2.3.3. Graduated cylinder: of $1000 \mathrm{~mL}$ with accuracy of $25 \mathrm{~mL}$ to determine the real density and volume of fruit by immersion in water.

2.3.4. Friction and rolling-angle measuring device: An inclined plane was used to measure friction and rolling angles. 
2.3.5. Friction angle measurement: the fruits are placed as a group bounded together on a horizontal surface then the angle of inclination is gradually increased until the fruits begin sliding without rolling. For each fruits group of an average sample of (10), the friction angles were determined.

2.3.6. Rolling angle measurement: the fruits are placed on a horizontal surface one by one then the angle of inclination is gradually increased until the fruits begin roll. For each fruit of an average sample (50), two angles of rolling are determined: for the maximum stable (with their base down) and minimum stable positions.

2.3.7. Penetrometer: Penetrometer, made in Italy, with accuracy of 0.1 $\mathrm{N}$ was used to measure penetration force of lemon fruits. The firmness of fruit was obtained by dividing the penetration force by the area $(0.28$ $\mathrm{cm}^{2}$ ) of cylindrical probe, which had $0.6 \mathrm{~cm}$ diameter.

\subsection{Studied factors and measurements:}

The studied factors of designed grading-machine were:

(1) Grading speed: Four different grading speeds 5, 8, 11 and $14 \mathrm{rpm}$ $(0.05,0.08,0.12$ and $0.15 \mathrm{~m} / \mathrm{s})$.

(2) Fruit batch: Four different feed rates of 5, 10, 15 and $20 \mathrm{~kg}$.

The measurements were: (1) grading efficiency, (2) fruit damage and (3) grading productivity.

\subsection{Equations and calculations:}

The following equations were used to calculate sphericity, projected area and real density according to Mohsenin, 1986.

Sphericity ratio $=$ fruit height $(\mathrm{H}) /$ fruit diameter (D)

Projected area $=4 / \pi(D * H)$

Real density $=$ Mass $/$ Volume

Grading productivity: Was calculated by using the following formula according to Amin (1994):

$$
\mathbf{P}=\frac{3600 * M}{T}
$$

Where: $\mathrm{P}=$ Grading productivity, $\mathrm{kg} / \mathrm{h}$. 


$$
\begin{aligned}
& \mathrm{M}=\text { Mass of sample, } \mathrm{kg} \text { and } \\
& \mathrm{T}=\text { Time in seconds. }
\end{aligned}
$$

Grading efficiency: The grading efficiency $(\boldsymbol{\mu})$ of each outlet has been calculated according to Amin (1994) as follows:

$\mu_{1}=M_{01} / M_{i 1}, \mu_{2}=M_{01} / M_{i 1}, \mu_{3}=M_{01} / M_{i 1}$, and $\mu_{4}=M_{01} / M_{i 1}$

Where: $\mu_{1}, \mu_{2}, \mu_{3}$ and $\mu_{4}$ : Grading efficiency of fruits for each outlet in the machine, $\%$.

$\mathbf{M}_{\mathbf{i 1}}, \mathbf{M}_{\mathbf{i} 2}, \mathbf{M}_{\mathbf{i} 3}$ and $\mathbf{M}_{\mathbf{i 4}}$ : Mass of each class inside fruit hopper, $\mathrm{kg}$ and

$$
\begin{gathered}
\mathbf{M}_{\mathbf{0 1}}, \mathbf{M}_{\mathbf{0 2}}, \mathbf{M}_{\mathbf{0 3}} \text { and } \mathbf{M}_{\mathbf{0 4}} \text { : Mass of the fruit for each outlet in the } \\
\text { machine, } \mathrm{kg} \text {. }
\end{gathered}
$$

Total grading efficiency: The total grading efficiency machine $(\boldsymbol{\mu})$ has been calculated using the following equation:

$$
\mu=\left(\mu_{1}+\mu_{2}+\mu_{3}+\mu_{4}\right) / 4
$$

Mechanical damage: Percentage of mechanical damage was calculated by using the following formula:

$$
\mathbf{D f}=\frac{N d}{N t} \times 100
$$

Where: $\mathrm{N}_{\mathrm{d}}=$ Number of damaged fruits and

$\mathrm{N}_{\mathrm{t}}=$ Total number of fruits.

Estimating the costs of using the machine: The operation cost of washing machine was calculated according to the following equation given by Awady, 1978 (updating 1998) modified for electrical motor drive:

$$
C=P / h(1 / a+I / 2+t+r)+(w . e)+m / 144
$$

Where: $\mathrm{C}=$ hourly cost, $\mathrm{P}=$ price of machine, $\mathrm{h}=$ yearly working-hours, $\mathrm{a}=$ life expected of machine, $\mathrm{I}=$ interest rate/year, $\mathrm{t}=$ taxes and overhead ratio, $\mathrm{w}=$ power of motor in $\mathrm{kW}, \mathrm{e}=$ hourly cost $/ \mathrm{kW} . \mathrm{h}$, and $\mathrm{m} / 144=$ monthly wage ratio.

Notice that all units have to be consistent to result in " $\mathrm{C}=\mathrm{LE} / \mathrm{h}$ ".

Operating cost $(\mathrm{L} . \mathrm{E} . / \mathrm{ton})=$ machine cost $(\mathrm{LE} / \mathrm{h}) /$ machine productivity (ton/h) 


\section{RESULTS AND DISCUSSION}

\subsection{Physical properties of lemon fruits.}

Table 1 shows dimensions, sphericity, mass, volume, real density and projected area, lemon fruits. These data were measured on 100 fruit sample, according to the standards set in (Mohsenin, 1986).

Table 1: Physical properties of lemon fruits.

\begin{tabular}{|l|c|c|c|c|c|}
\hline Physical properties & Max. & Min. & Average & S. D. $^{(\mathbf{1})}$ & C. V. $^{(\mathbf{2})}$ \\
\hline Height, mm & 43 & 27 & 36 & 4.36 & 12.12 \\
\hline Diameter, mm & 49 & 28 & 38.3 & 5.73 & 14.93 \\
\hline Sphericity & 1.1 & 0.9 & 0.9 & 0.06 & 5.97 \\
\hline Mass, g & 50 & 15 & 29.7 & 10.32 & 34.75 \\
\hline Volume, $\mathbf{c m}^{\mathbf{3}}$ & 45 & 17 & 28 & 8.51 & 29.83 \\
\hline Bulk density, $\mathbf{g} / \mathbf{c m}^{\mathbf{3}}$ & \multicolumn{5}{|l|}{0.59} \\
\hline Real density, $\mathbf{g} / \mathbf{c m}^{\mathbf{3}}$ & 1.1 & 0.7 & 0.9 & 0.15 & 16.62 \\
\hline Projected area, $\mathbf{c m}^{\mathbf{2}}$ & 27 & 4.7 & 10 & 4.68 & 26.17 \\
\hline
\end{tabular}

(1) S. D. is standard deviation.

(2) C. V. is coefficient of variation.

\subsubsection{Dimensions of fruit:}

Fig. 6 indicates that the fruit diameter and height ranges of sample were $30-50 \mathrm{~mm}$ (average $38.35 \mathrm{~mm}$ ) and $30-45 \mathrm{~mm}$ (average 36.01 $\mathrm{mm})$ respectively. The most frequent percent $(80 \%)$ of lemon fruits in the sample have $40-50 \mathrm{~mm}$ diameter and $(90 \%)$ of lemon fruits in the sample have 35 - $45 \mathrm{~mm}$ height.

\section{3a2. Shape and size of fruit:}

If sphericity is less than 0.9 , the fruit belongs to oblate group; if sphericity is greater than 1.1 , it belongs to oblong group. The remaining fruits with intermediate index values are considered to be round (Buyanov and Voronyuk, 1985). Fig. 7 indicates that the fruit spericity ranged in sample between 0.9 and 1.1. The most frequent percent (100 $\%$ ) of lemon fruits in the sample was round (sphericity $0.9-1.1$ ).

\section{$\underline{\text { 3a3. Mass and volume of fruit: }}$}


Fig. 8 indicates that the fruit mass and volume ranges of sample were 15 - $50 \mathrm{~g}$ (average $29.7 \mathrm{~g}$ ) and $17-45 \mathrm{~cm}^{3}$ (average $28 \mathrm{~cm}^{3}$ ) respectively. The most frequent percent $(70 \%)$ of lemon fruits in the sample had 30 $40 \mathrm{~g}$ mass and $(80 \%)$ had $20-40 \mathrm{~cm}^{3}$ volume.

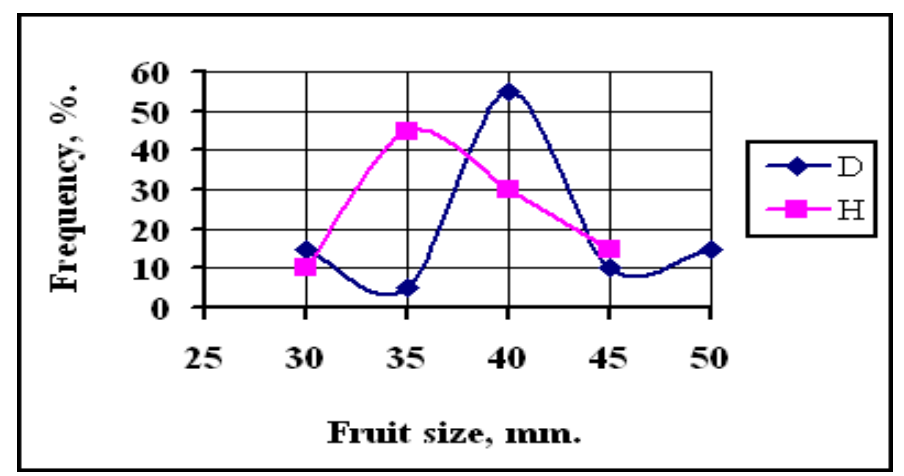

Fig. 6 : Frequency curves distribution of fruit dimensions (diameter "D" and height "H") .

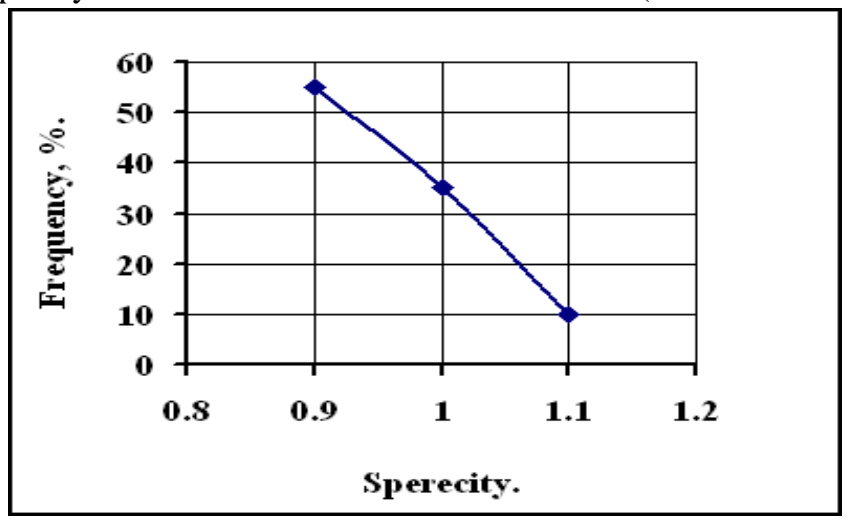

Fig. 7: Frequency curves distribution of fruit sphericity of lemon fruits.

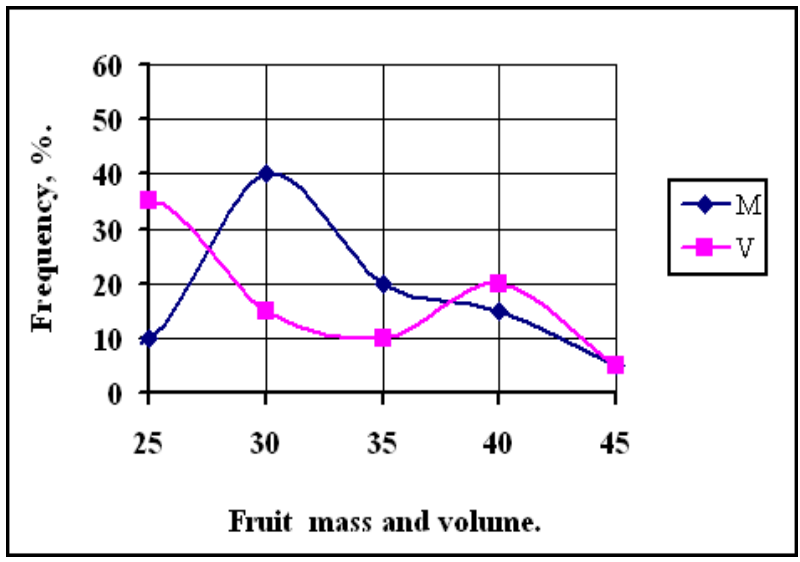

Fig. 8: Frequency curves distribution of fruit mass and volume of lemon fruits. 


\subsection{Mechanical properties of lemon fruits:}

\subsection{Friction, rolling and repose angles of lemon fruits:}

Table 2 shows friction and rolling angles of lemon fruits. The maximum friction angle (38 - 43 degree) and rolling angle ranges (23 - 32 degree) were obtained with wood surface. Whereas, the minimum range of friction angle of 14 - 16 was obtained with PVC surface and minimum rolling angle of 10 - 24 was obtained with aluminium surface.

Table 2: Friction and rolling angles for lemon fruits with different surface types.

\begin{tabular}{|c|c|c|c|c|c|c|c|c|c|}
\hline \multirow{2}{*}{$\begin{array}{c}\text { Surface } \\
\text { type }\end{array}$} & \multicolumn{3}{|c|}{$\begin{array}{c}\text { Friction angle, } \\
\text { degree }\end{array}$} & \multicolumn{4}{|c|}{ Rolling angle, degree } \\
\cline { 2 - 10 } & Max. & Min. & Av. & Max. & Min. & Av. & Max. & Min. & Av. \\
\hline Wood & 43 & 38 & 40 & 32 & 23 & 28 & 22 & 17 & 20.5 \\
\hline Metal & 17 & 15 & 15.2 & 24 & 23 & 22.4 & 14 & 11 & 12.5 \\
\hline Galv. I. & 17 & 15 & 14.6 & 24 & 23 & 22.6 & 14 & 11 & 12.7 \\
\hline Alum. & 17 & 14 & 14.4 & 24 & 21 & 22.2 & 14 & 10 & 12.3 \\
\hline SS & 17 & 15 & 14.5 & 24 & 23 & 21.3 & 14 & 11 & 12.4 \\
\hline PVC & 16 & 14 & 14.0 & 24 & 23 & 21.1 & 14 & 11 & 12.4 \\
\hline
\end{tabular}

Wood: wood sheet No. 2; Galv. I.: Galvanized iron; Alum.: Aluminium; and SS.: Stainless steal.

The average repose-angle was about 38.8 degree.

\section{$\underline{\text { 3c. Effect of grading speed and fruit batch on grading efficiency: }}$}

Fig. 9 shows the effect of grading speed and fruit batch on grading efficiency of four fruit-sizes.

The maximum grading efficiencies of $91.8,93,94.4,100$ and $94.8 \%$ for fruit sizes $35,40,40,>45 \mathrm{~mm}$ and total respectively were obtained with grading speed of $11 \mathrm{rpm}(0.12 \mathrm{~m} / \mathrm{s})$ and fruit batch of $5 \mathrm{~kg}$. Meanwhile, the minimum grading efficiencies of $76,81.3,82.7,100$ and $81.1 \%$ for fruit sizes $35,40,40,>45 \mathrm{~mm}$ and total respectively were obtained with grading speed of $14 \mathrm{rpm}(0.15 \mathrm{~m} / \mathrm{s})$ and fruit batch of $20 \mathrm{~kg}$. The 
decreasing of grading efficiency by increasing grading speed and fruit batch is due to decreasing the time of grading and accumulating of fruits on drum holes respectively.

\subsection{Effect of grading speed and fruit batch on fruit damage:}

Table 3 shows the effect of grading speed and fruit batch on fruit damage of four fruit-sizes. The maximum fruit damage of 4.7, 4.1 and $8.9 \%$ for fruit sizes $35,40 \mathrm{~mm}$ and total respectively were obtained with grading speed of $8 \mathrm{rpm}(0.08 \mathrm{~m} / \mathrm{s})$ and fruit batch of $20 \mathrm{~kg}$. Meanwhile, the minimum fruit-damage of zero $\%$ for all fruit sizes was obtained with grading speed of $11-14 \mathrm{rpm}(0.12-0.15 \mathrm{~m} / \mathrm{s})$ and fruit batch of $5 \mathrm{~kg}$.

The caused fruit-damage by using grading speed of 5 and $8 \mathrm{rpm}(0.05$ and $0.08 \mathrm{~m} / \mathrm{s}$ ) is due to fruit jamming between fruit cutoff and grading drum.

\subsection{Effect of grading speed and fruit batch on machine productivity:}

Fig. 10 shows the effect of grading speed and fruit batch on gradingmachine productivity. The maximum range of grading-machine productivity for lemon fruits of $220.7-760.9 \mathrm{~kg} / \mathrm{h}$ was obtained with grading speed range of $5-14 \mathrm{rpm}(0.05-0.15 \mathrm{~m} / \mathrm{s})$ and fruit batch of $20 \mathrm{~kg}$. Meanwhile, the minimum range of grading-machine productivity for lemon fruits of $142.8-492.3 \mathrm{~kg} / \mathrm{h}$ was obtained with grading speed range of $5-14 \mathrm{rpm}(0.05-0.15 \mathrm{~m} / \mathrm{s})$ and fruit batch of $5 \mathrm{~kg}$. The increasing of grading-machine productivity by increasing grading speed and fruit batch is due to decreasing the time of grading and fruit mass respectively.

\section{3f. Cost of using the designed grading-machine.}

Table 4 shows the components of the Awady equation. The operation and production costs were 7.37 L.E./h and $64.84,19.8$ L.E./ton at optimum conditions (grading speed of $11 \mathrm{rpm}$ or $0.12 \mathrm{~m} / \mathrm{s}$ and fruit batch of $10 \mathrm{~kg}$ ). 


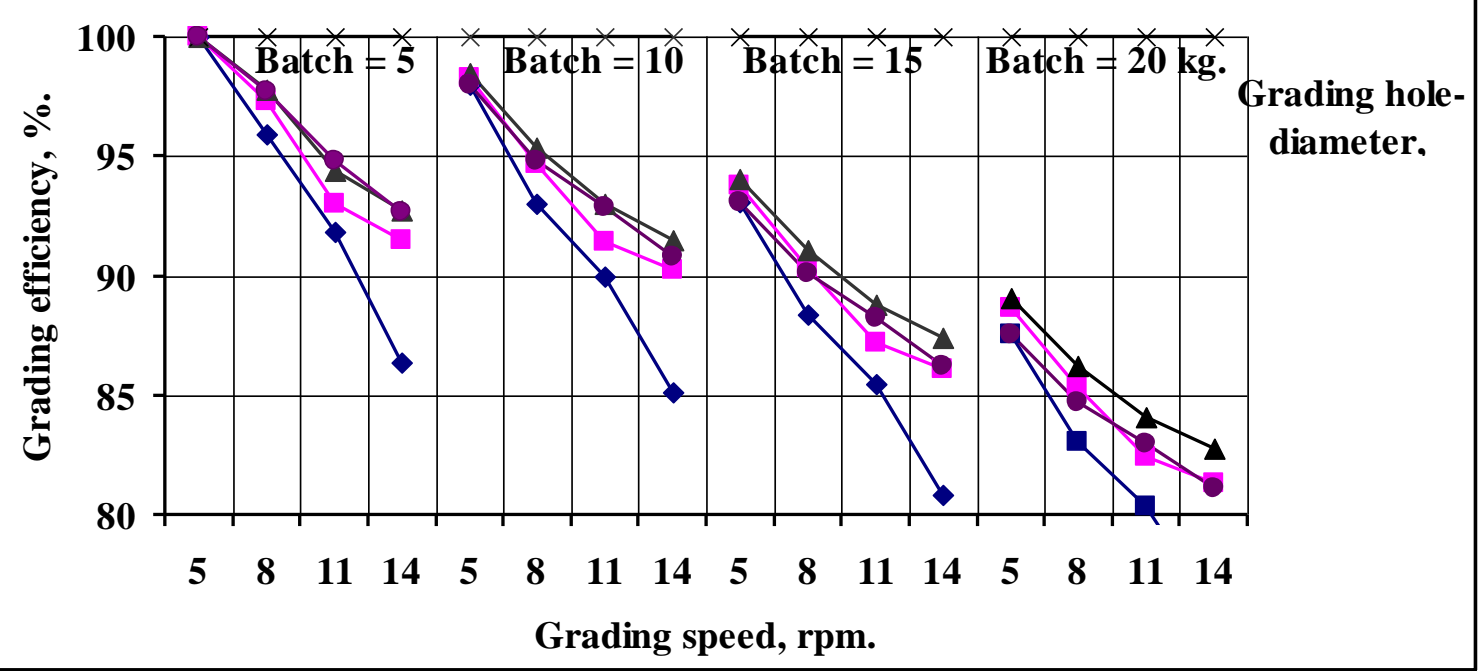

Fig 9 : Effect of grading speed, hole diameter of grading drums and fruit batch on machine grading-efficiency.

Table 3: Effect of grading speed, fruit batch-mass and fruit size on fruit damage.

\begin{tabular}{|c|c|c|c|c|c|c|}
\hline \multirow{2}{*}{$\begin{array}{c}\text { Fruit } \\
\text { batch, } \\
\text { kg }\end{array}$} & $\begin{array}{c}\text { Grading } \\
\text { speed, } \\
\text { rpm. }\end{array}$ & \multicolumn{5}{|c|}{ Fruit damage, \%. } \\
\cline { 2 - 7 } & $\mathbf{5}$ & 35 & $\mathbf{4 0}$ & $\mathbf{4 5}$ & $\mathbf{7 4 5}$ & Total \\
\hline \multirow{4}{*}{5} & $\mathbf{8}$ & 4.1 & 3.5 & 0.0 & 0.0 & 6.6 \\
\cline { 2 - 7 } & $\mathbf{1 1}$ & 0.0 & 0.0 & 0.0 & 0.0 & 7.6 \\
\cline { 2 - 7 } & $\mathbf{1 4}$ & 0.0 & 0.0 & 0.0 & 0.0 & 0.0 \\
\hline \multirow{4}{*}{$\mathbf{1 0}$} & $\mathbf{5}$ & 3.2 & 3.6 & 0.0 & 0.0 & 0.0 \\
\cline { 2 - 7 } & $\mathbf{8}$ & 4.2 & 3.6 & 0.0 & 0.0 & 7.8 \\
\cline { 2 - 7 } & $\mathbf{1 1}$ & 0.0 & 0.0 & 0.0 & 0.0 & 0.0 \\
\cline { 2 - 7 } & $\mathbf{1 4}$ & 0.0 & 0.0 & 0.0 & 0.0 & 0.0 \\
\hline \multirow{4}{*}{$\mathbf{1 5}$} & $\mathbf{5}$ & 3.4 & 3.8 & 0.0 & 0.0 & 7.2 \\
\cline { 2 - 7 } & $\mathbf{8}$ & 4.4 & 3.9 & 0.0 & 0.0 & 8.3 \\
\cline { 2 - 7 } & $\mathbf{1 1}$ & 0.0 & 0.0 & 0.0 & 0.0 & 0.0 \\
\cline { 2 - 7 } & $\mathbf{1 4}$ & 0.0 & 0.0 & 0.0 & 0.0 & 0.0 \\
\hline \multirow{4}{*}{$\mathbf{2 0}$} & $\mathbf{5}$ & 3.6 & 4.1 & 0.0 & 0.0 & 7.7 \\
\cline { 2 - 7 } & $\mathbf{8}$ & 4.7 & 4.1 & 0.0 & 0.0 & 8.9 \\
\cline { 2 - 7 } & $\mathbf{1 1}$ & 0.0 & 0.0 & 0.0 & 0.0 & 0.0 \\
\cline { 2 - 7 } & $\mathbf{1 4}$ & 0.0 & 0.0 & 0.0 & 0.0 & 0.0 \\
\hline
\end{tabular}


Table 4: The components of Awady equation.

\begin{tabular}{|c|c|c|c|c|c|c|c|c|}
\hline $\begin{array}{c}\mathrm{p}, \\
\text { L.E. }\end{array}$ & $\mathrm{h}, \mathrm{h}$ & $\begin{array}{c}\mathrm{a}, \\
\text { year }\end{array}$ & $\mathrm{i}$ & $\mathrm{t}$ & $\mathrm{r}$ & $\mathrm{Ec}, \mathrm{kW} . \mathrm{h} / \mathrm{h}$ & $\begin{array}{c}\mathrm{Ep}, \\
\text { L.E. }\end{array}$ & $\begin{array}{c}\mathrm{m}, \\
\mathrm{L} . \mathrm{E}\end{array}$ \\
\hline 2000 & 1500 & 10 & 0.075 & 0.05 & 0.03 & 0.4 & 0.25 & 1000 \\
\hline
\end{tabular}

$\mathrm{C}=2000 / 1500 *(0.1+0.035+0.05+0.06)+0.4 * 0.25+1000 / 144$

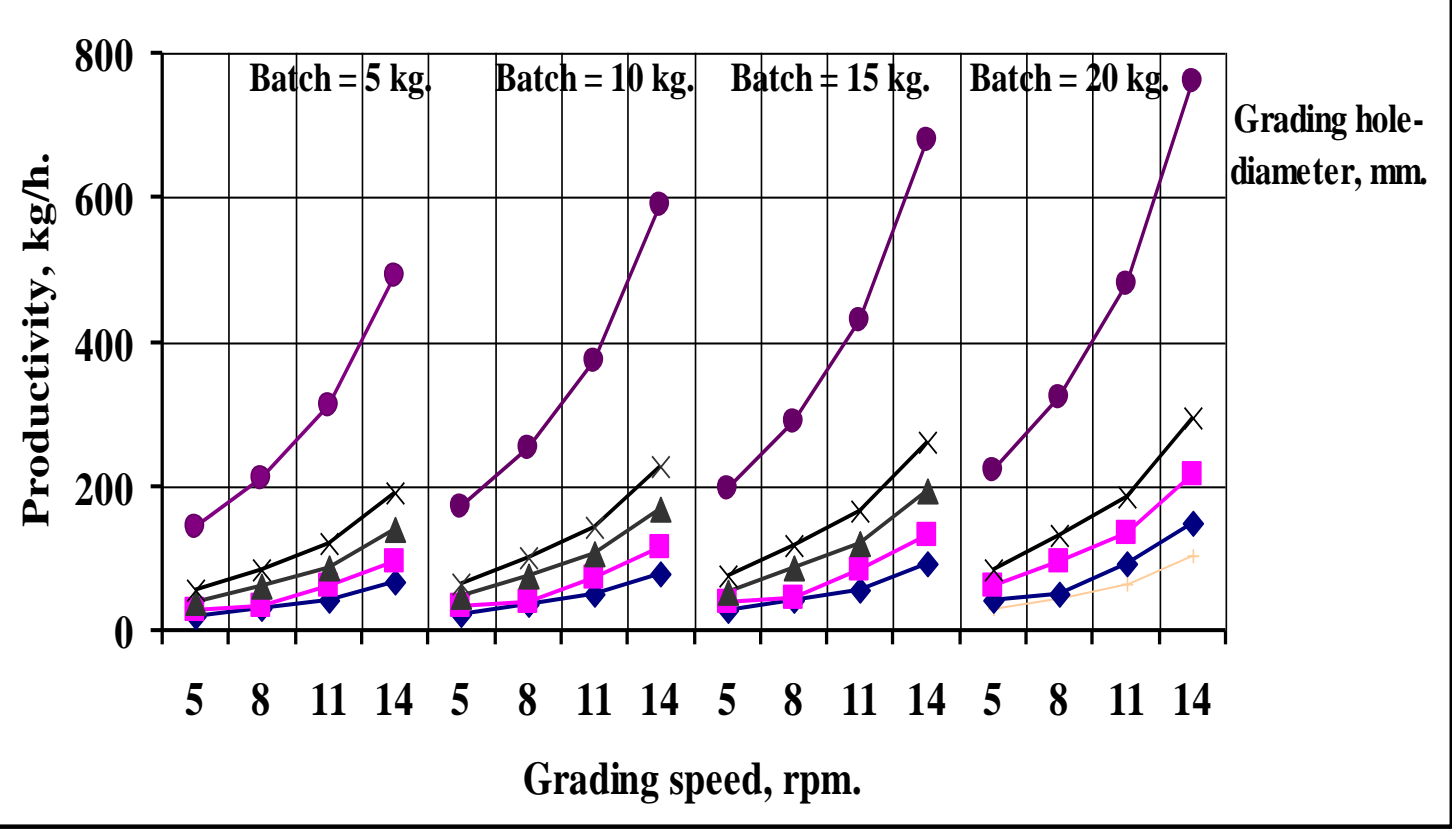

Fig. 9: Effect of grading speed, hole diameter of grading drums and fruit batch on machine grading-productivity.

\section{CONCLUSION}

The main results in this study can be summarized as follows:

The maximum fruit damage of $8.9 \%$ was obtained with grading speed of $8 \mathrm{rpm}(0.08 \mathrm{~m} / \mathrm{s})$ and fruit batch of $20 \mathrm{~kg}$. Meanwhile, the minimum fruit-damage of zero \% was obtained with grading speed of $11-14 \mathrm{rpm}$ $(0.12-0.15 \mathrm{~m} / \mathrm{s})$ and fruit batch of $5 \mathrm{~kg}$. The maximum range of grading- 
machine productivity for lemon fruits of $220.7-760.9 \mathrm{~kg} / \mathrm{h}$ was obtained with grading speed range of $5-14 \mathrm{rpm}(0.05-0.15 \mathrm{~m} / \mathrm{s})$ and fruit batch of $20 \mathrm{~kg}$. Meanwhile, the minimum range of grading-machine productivity for lemon fruits of $142.8-492.3 \mathrm{~kg} / \mathrm{h}$ was obtained with grading speed range of $5-14 \mathrm{rpm}(0.05-0.15 \mathrm{~m} / \mathrm{s})$ and fruit batch of 5 $\mathrm{kg}$. The operation and production costs were 7.37 L.E./h and 64.84, 19.8 L.E./ton at optimum conditions (grading speed of $11 \mathrm{rpm}$ or $0.12 \mathrm{~m} / \mathrm{s}$ and fruit batch of $10 \mathrm{~kg}$ ).

\section{REFERENCES}

Abd-Alla, H. El. S. M. Radwan M. M. El-Kholy and M. S. Radwan (2000). A weight grading machine for fifferent fruits and vegetables. Misr. J. Agic. Eng., 17(3): 675-696.

Amin, E. E., 1994, Development of a grading machine for some horticulture farm crops, J.Agric. Sci. Mansoura Univ. 19(7) :31393149 .

Awady, M. N., 1978, (updating 1998), Engineering of tractors and Agricultural machinery. TextBook., col. Ag., Ain-shams Univ., 5 th. Ed.,: 164-167. (In Arabic).

Buyanov, A. I. And Voronyuk, B. A., 1985, Physical and mechanical properties of plants, Fertilizers and Soils, Amerind Pub. Co., PVT, LTD, New Delhi, Bombay, Calcutta, New York: 15 - 97.

Mohsenin, N. N., 1986, Physical properties of plant and animal materials, Gordon and Breach Sc. Pub., N. Y.

Mousa, M. M., 1998, Engineering factors affecting the development of grading machine for citrus, Ph. D., Fac. of Ag., Cairo U.: 126-255. 
Radwan, M.S.M. (2000). A weight grading machine for different fruit and vegetables. M.Sc. Thesis, Agric. Eng. Dept. Fac. Of Agric.,. Mansoura Univ.

Yehia, I., Kabeel, M., Abdel Galeel, M. M., 2009, Physical and mechanical properties of Ponkan mandarin applied to grading machine, Misr J. Ag. Eng. 26(2): 1036-1053.

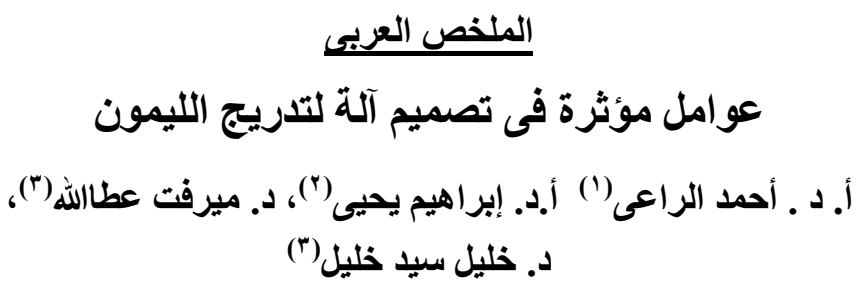

تمثل الموالح فى مصر المرتبة الاولى من حيث الأهمية والمساحة المنزرعة' ويعتبر الليمون

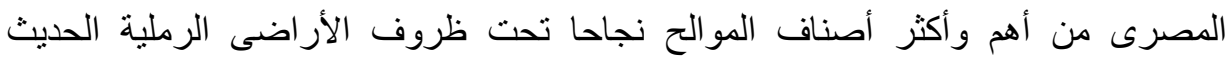

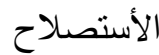

تهذف هذه الدراسة إلى تصميم آلة لتدريج ثمار الليمون باستخدام الخواص الطبيعية لها، وتتكون

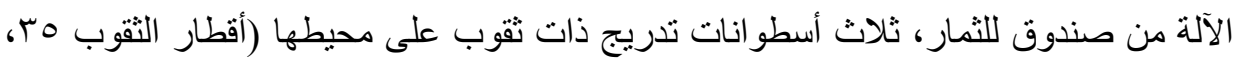

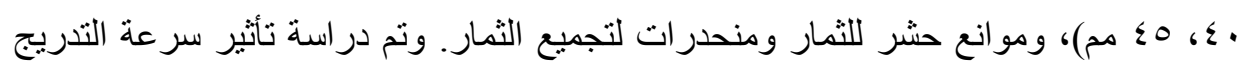

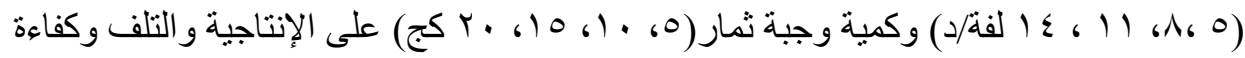
التدريج. وتم الحصول على النتائج التالية: (1) تأثثر سرعة أسطوانات التدريج وكمية الثمار على كفاءة التدريج: تأثيرِ السرعةِ وكميةِ

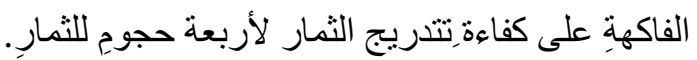

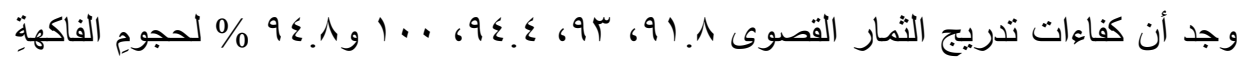

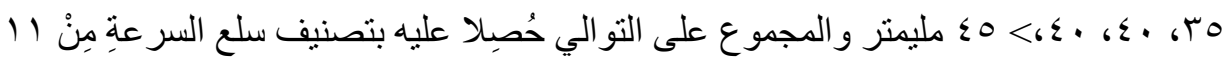

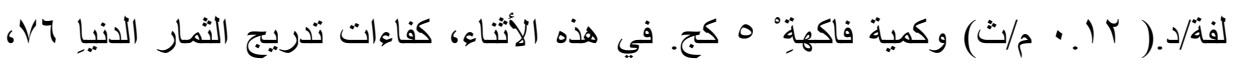

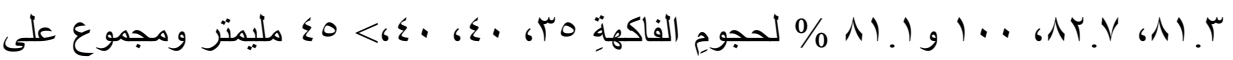

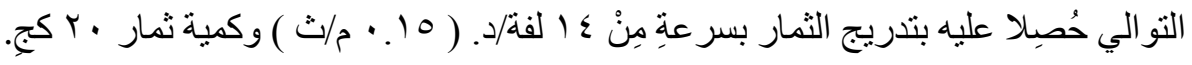
كفاءة تدريج الثمار تتقص بزيادة سر عةِ تدريج الثمار ومعدل التغذية .

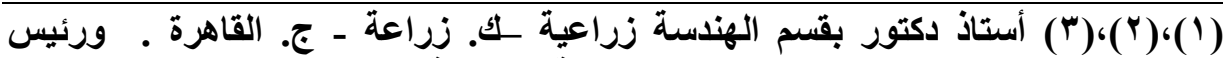

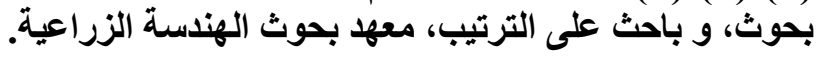




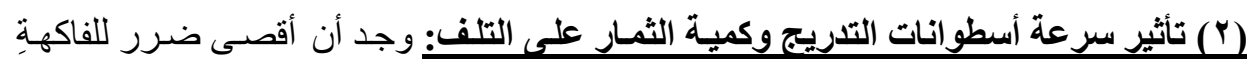

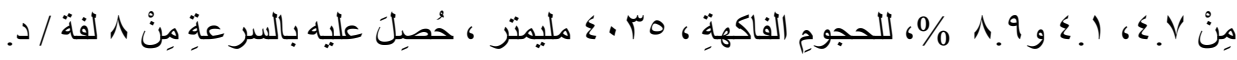

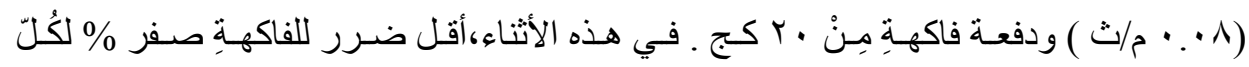

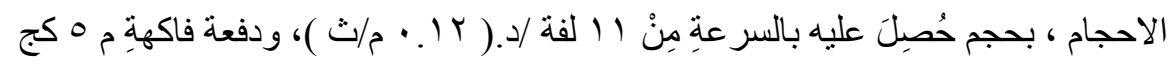

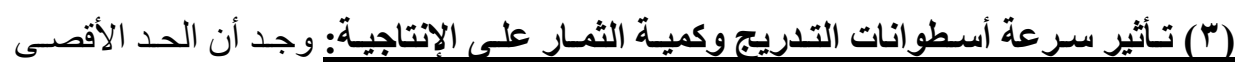

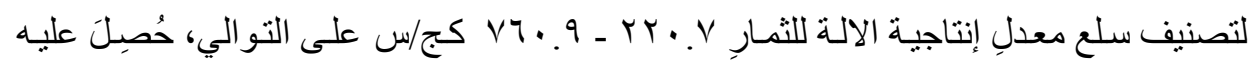

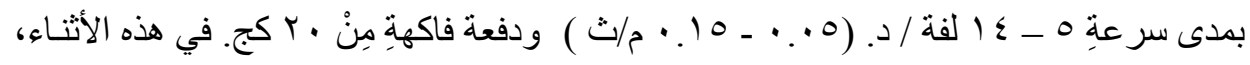

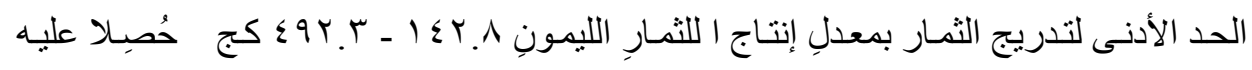

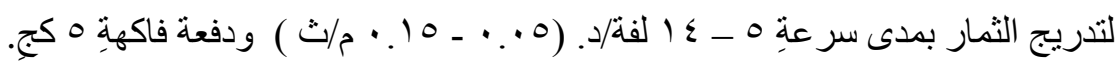

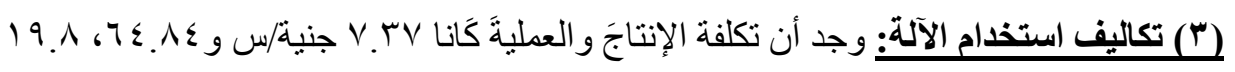

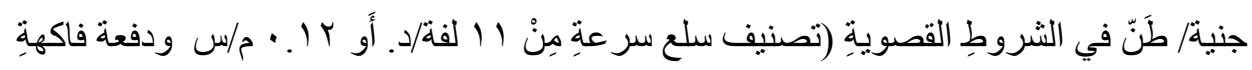

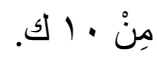

